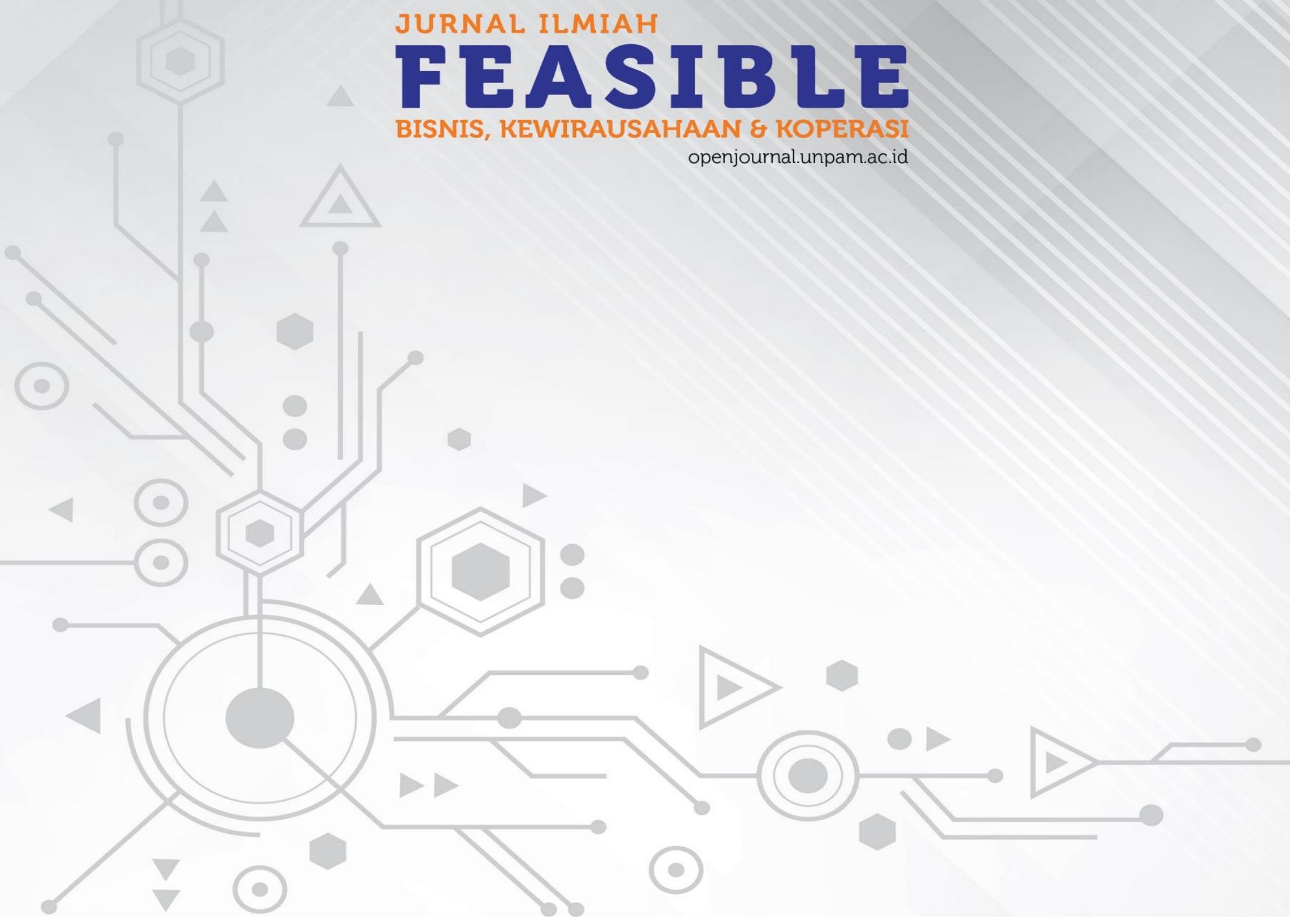


P-ISSN:2655-9811, E-ISSN:2656-1964

J. Feasible., Vol. 1, No.2, Agustus 2019 (196-207)

C 2019 Pusat In kubasiBisn is dan Ke w irausahaan

UniversitasPamulang (PINBIKUNPAM) эunas пиман

FEASIBLE

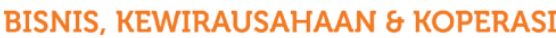

\title{
PENGARUH PROBLEM SOLVING SKILL DAN KOMUNIKASI EFEKTIF TERHADAP PRODUKTIVITAS KARYAWAN
}

\author{
Hira Maulida \\ Fakultas Ekonomi, Universitas Pamulang \\ hiramaulidaa@gmail.com
}

\begin{abstract}
Abstrak
Tujuan dari penelitian ini adalah untuk mengetahui pengaruh problem solving skill terhadap produktivitas karyawan, untuk mengetahui pengaruh komunikasi efektif terhadap produktivitas karyawan, untuk mengetahui pengaruh problem solving skill dan komunikasi efektif secara simultan terhadap produktivitas karyawan di PT. Reckitt Benckiser Indonesia. Metode yang digunakan dalam penelitian ini adalah deskriptif kuantitatif dalam uji statistik untuk mengetahui apakah terdapat pengaruh antara variabel yang diteliti dan proses perhitungan statistik lainnya menggunakan program STATA versi 14.2. Populasi dalam penelitian ini adalah 319 karyawan di PT Reckitt Benckiser Indonesia dan menggunakan rumus Slovin. 177 orang dijadikan sampel untuk menentukan responden. Hasil dari penelitian ini adalah problem solving skill berpengaruh terhadap produktivitas karyawan, komunikasi efektif berpengaruh terhadap produktivitas karyawan, problem solving skill dan komunikasi efektif berpengaruh terhadap produktivitas karyawan.
\end{abstract}

Kata Kunci: Problem Solving Skill, Komunikasi Efektif, Produktivitas Karyawan.

\begin{abstract}
The purpose of this study was to determine the effect of Problem solving skill on employees productivity, to determine the effect of effective communication on employees productivity, to determine the effect of Problem solving skill and effective communication simultaneously on employees productivity at PT. Reckitt Benckiser Indonesia. The method used in this study is descriptive quantitative in statistical tests are to find out whether there is an influence among the variables studied and other statistical calculation processes using the STATA version 14.2 program. The population in this study was 319 employees at PT Reckitt Benckiser Indonesia and using the Slovin formula. 177 people used as samples for determining respondents. The result of this study is Problem solving skill has an effect on employees productivity, effective communication has an effect on employees productivity, Problem solving skill and effective communication has an effect on employees productivity.
\end{abstract}

Keywords: Problem Solving Skill, Effective Communication, Employees productivity. 


\section{PENDAHULUAN}

\section{Latar Belakang}

PT. Reckitt Benckiser merupakan perusahaan pemimpin global untuk perusahaan yang memproduksi produk consumer goods bidang kesehatan, kebersihan, dan perawatan rumah tangga. Saat ini PT. Reckitt Beckiser menduduki peringkat pertama dan kedua sebagai perusahaan terbesar untuk kategori Fast Moving Consumer Goods dengan 19 merek terkenalnya di bidang kesehatan, kebersihan, perawatan rumah dan nutrisi. Di kategori nutrisi seperti Enfagrow dan Sustagen. Di kategori perawatan rumah termasuk yang dijual Over The Counter (OTC) seperti Mucinex, Durex, Nurofen, Strepsils Gavicson dan Scholl, serta di kategori kesehatan seperti Vanish, Lysol, Dettol, Clearasil, Veet, Harpic, Bang, dan Mortein.

(Kepner Tregoe,2017) menyatakan bahwa "Problem solving skill adalah suatu metode untuk mengetahui permasalahan yang terjadi dalam organisasi, mengidentifikasi hal-hal yang ingin kita ketahui dan membentuknya dengan berupa penyelesaian masalah". Di dalam perusahaan PT Reckitt Benckiser Indonesia, karyawan bekerja bersama dengan berbagai tipe dan karakteristik orang masing-masing dan tak jarang karyawan memiliki perbedaan pendapat dan persepsi dalam menyelesaikan permasalahan dalam perusahaaan serta perbedaan cara pemikiran antar karyawan dalam menyelesaikan permasalahan sedangkan untuk permasalahan dalam perusahaan dibutuhkan ketepatan, kecepatan dan ketegasan dalam membuat keputusan untuk menyelesaikan permasalahan kerja.

(Yosal Iriantara,2014) mengemukakan bahwa "Komunikasi efektif adalah proses untuk menyampaikan pesan berupa informasi, ide, gagasan, opini, ekspresi dan emosi untuk suatu tujuan tertentu". Kurangnya komunikasi akan menjadi kendala yang mempengaruhi kelancaran kegiatan perusahaan. Dapat dilihat dengan adanya miskomunikasi antara karyawan yang terjadi karena perbedaan persepsi antara informasi yang disampaikan oleh karyawan yang satu dan informasi yang diterima oleh karyawan lainnya. Masih ada miskomunikasi antara karyawan. Pimpinan perusahaan tidak memiliki komunikasi yang baik dengan karyawan. Informasi yang disampaikan oleh para pemimpin tidak dipahami dengan baik oleh karyawan. Pemimpin tidak selalu menanggapi saran dari karyawan. Karyawan belum terbuka dalam mengungkapkan pendapat kepada pimpinan. Kurangnya keharmonisan dan keterbukaan dalam proses komunikasi antar karyawan. Masih sering terjadi kesalahan dalam mekanisme kerja. Karyawan tidak bisa bekerja sama dengan baik. Masih ada karyawan yang tidak jujur di tempat kerja untuk menyalah gunakan kepercayaan yang 
telah diberikan. Strategi kinerja yang diterapkan oleh perusahaan belum efektif. Masih ada karyawan yang datang terlambat untuk briefing.

(Sutrisno, 2012) mengemukakan bahwa "Produktivitas karyawan adalah pencapaian kinerja yang dicapai oleh karyawan dengan target tujuan yang telah ditentukan". Produktivitas karyawan PT Reckitt Benckiser Indonesia tidak optimal. Selain itu produktivitas karyawan karyawan di PT. Reckitt Benckiser Indonesia pada 2009-2017 dapat dilihat pada Tabel 1 sebagai berikut:

\begin{tabular}{|cccc|}
\hline \multicolumn{4}{|c}{$\begin{array}{c}\text { Tabel 1.1. Data Produktivitas Karyawan } \\
\text { PT. Reckitt Benckiser Indonesia }\end{array}$} \\
\hline Year & Target & Realization & $\begin{array}{c}\text { Achievement in } \\
\text { Percentages }\end{array}$ \\
\hline $\mathbf{2 0 0 9}$ & $709,607,564,788$ & $778,478,365,261$ & 92,2 \\
\hline $\mathbf{2 0 1 0}$ & $831,000.431,145$ & $890,647,285,442$ & 92,0 \\
\hline $\mathbf{2 0 1 1}$ & $922,463,671,121$ & $967,559,197,343$ & 92,4 \\
\hline $\mathbf{2 0 1 2}$ & $1.180,451,244,655$ & $1.070,615,339,178$ & 90,6 \\
\hline $\mathbf{2 0 1 3}$ & $1,132,992,422,890$ & $1,234,875,921,870$ & 109,2 \\
\hline $\mathbf{2 0 1 4}$ & $1,416,974 \cdot 322.565$ & $1,339,974,735,335$ & 94,5 \\
\hline $\mathbf{2 0 1 5}$ & $1,775,586,578,340$ & $1,718,039,728,279$ & 96,7 \\
\hline $\mathbf{2 0 1 6}$ & $2,102,109,897,688$ & $2,002,491,535,950$ & 95,2 \\
\hline $\mathbf{2 0 1 7}$ & $2,525,915,657,120$ & $2,242,724,560,662$ & 88,7 \\
\hline $\mathbf{2 0 1 8}$ & $2,628,555,764,144$ & $2,291,168,177,930$ & 87,1 \\
\hline
\end{tabular}

Sumber : HRD PT Reckitt Benckiser Indonesia

Berdasarkan data pada tabel 2 di atas, PT. Reckitt Benckiser mencapai persentase tertinggi pada 2012 sebesar 109,2\%. Persentase penurunan pada 2013 sebesar 94,5\%. PT. Reckitt Benckiser mengalami peningkatan persentase pada tahun 2014 sebesar 96,7\%. Namun, ada penurunan persentase pencapaian kembali pada tahun 2015 sebesar 95,2\% dan demikian juga penurunan persentase pencapaian pada tahun 2016 yang menurun sebesar 88,7\%.
PT. Reckitt Benckiser mencapai persentase terendah pada 2018 yaitu $87,1 \%$.

Berdasarkan permasalahan yang terjadi pada PT Reckitt Benckiser Indonesia, maka penelitian bertujuan untuk mengetahui:

1. Pengaruh Problem Solving Skill terhadap Produktivitas Karyawan di PT. Reckitt Benckiser Indonesia.

2. Pengaruh Komunikasi Efektif terhadap Produktivitas Karyawan di PT. Reckitt Benckiser Indonesia.

3. Pengaruh Problem Solving Skill dan Komunikasi Efektif secara simultan terhadap Produktivitas Karyawan di PT. Reckitt Benckiser Indonesia.

\section{Kajian Literatur}

(Berny Gomulya, 2012) menyatakan bahwa "Problem Solving Skill adalah keterampilan yang mencakup kemampuan untuk mencari informasi, menganalisis situasi, mengidentifikasi masalah untuk menghasilkan tindakan alternatif, kemudian mempertimbangkan alternatif ini sehubungan dengan hasil yang dicapai dan akhirnya mengimplementasikan rencana dengan mengambil tindakan yang benar". Indikator yang terkandung dalam Problem Solving Skill termasuk mengidentifikasi masalah, mendefinisikan masalah, mengatur informasi, membentuk strategi, mengalokasikan sumber daya, membuat keputusan, pemantauan dan evaluasi. 
Sedangkan menurut (Arina Nikitina, 2018) "Problem Solving Skill adalah kemampuan membuat keputusan yang percaya diri, dapat mengendalikan situasi, dan menyalurkan dukungan dan energi serta memiliki proses penyelesaian masalah yang baik".

(Feriyanto Andri, 2015) menyatakan bahwa "Komunikasi yang efektif adalah proses penyampaian informasi dalam bentuk pesan, ide, ide dari satu pihak ke pihak lain untuk mencapai persepsi yang dapat dipahami atau dipahami sama, komunikasi dapat dilakukan secara verbal dan nonverbal.

Sedangkan menurut (Yosal Iriantara, 2014) "Komunikasi Efektif adalah suatu proses penyampaian pesan dalam bentuk informasi, gagasan, pemikiran, pendapat, pengetahuan, ekspresi perasaan untuk tujuan tertentu" Indikator yang terkandung dalam komunikasi yang efektif meliputi pemahaman, pengaruh pada sikap , penyampaian pesan, keterbukaan informasi, umpan balik, hubungan baik dan memperluas keterampilan komunikasi.

(Sutrisno, 2012) mengemukakan bahwa "Produktivitas karyawan adalah hasil yang dicapai oleh karyawan dengan tujuan yang telah ditentukan”. Indikator yang terkandung dalam produktivitas meliputi kemampuan, hasil yang meningkat, semangat di tempat kerja, pengembangan diri, kualitas dan efisiensi. Produktivitas dapat diartikan sebagai prestasi kerja hasil kerja.

Sedangkan menurut Naeem Akhtar (2014) "Produktivitas adalah perbandingan antara output dan input yang merupakan suatu ukuran yang menyatakan bagaimana sebaiknya sumber daya diatur dan dimanfaatkan untuk mencapai hasil yang optimal. Produktivitas dapat digunakan sebagai tolok ukur keberhasilan suatu industri. Ukuran produktivitas dapat diperiksa secara kolektif (di seluruh ekonomi) atau dilihat industri demi industri”.

\section{METODE}

Penelitian ini dilakukan di PT. Reckitt Benckiser Indonesia, beralamat di Gedung Artha Graha - Lantai 11, Jl. Jend Sudirman Kav. 52-53, RT.5 / RW.3, Senayan, Kebayoran Baru, Jakarta Selatan, DKI Jakarta 12190, Indonesia. Penelitian ini dilakukan pada Maret 2019-Juni 2019. Metode yang digunakan dalam penelitian kuantitatif ini adalah analisis deskriptif. Dalam uji statistik adalah untuk mengetahui apakah ada pengaruh antara variabel yang diteliti dan proses perhitungan statistik lainnya menggunakan program STATA versi 14.2. Populasi dalam penelitian ini adalah 319 karyawan di PT Reckitt Benckiser Indonesia Jakarta dan menggunakan rumus Slovin untuk menentukan responden maka 177 orang dijadikan sampel dalam penelitian. 
Variabel dalam penelitian ini terdiri dari dua variabel independen yaitu Problem Solving Skill dan Komunikasi Efektif, dan satu variabel dependen adalah produktivitas karyawan.

\section{HASIL dan PEMBAHASAN}

Uji Validitas

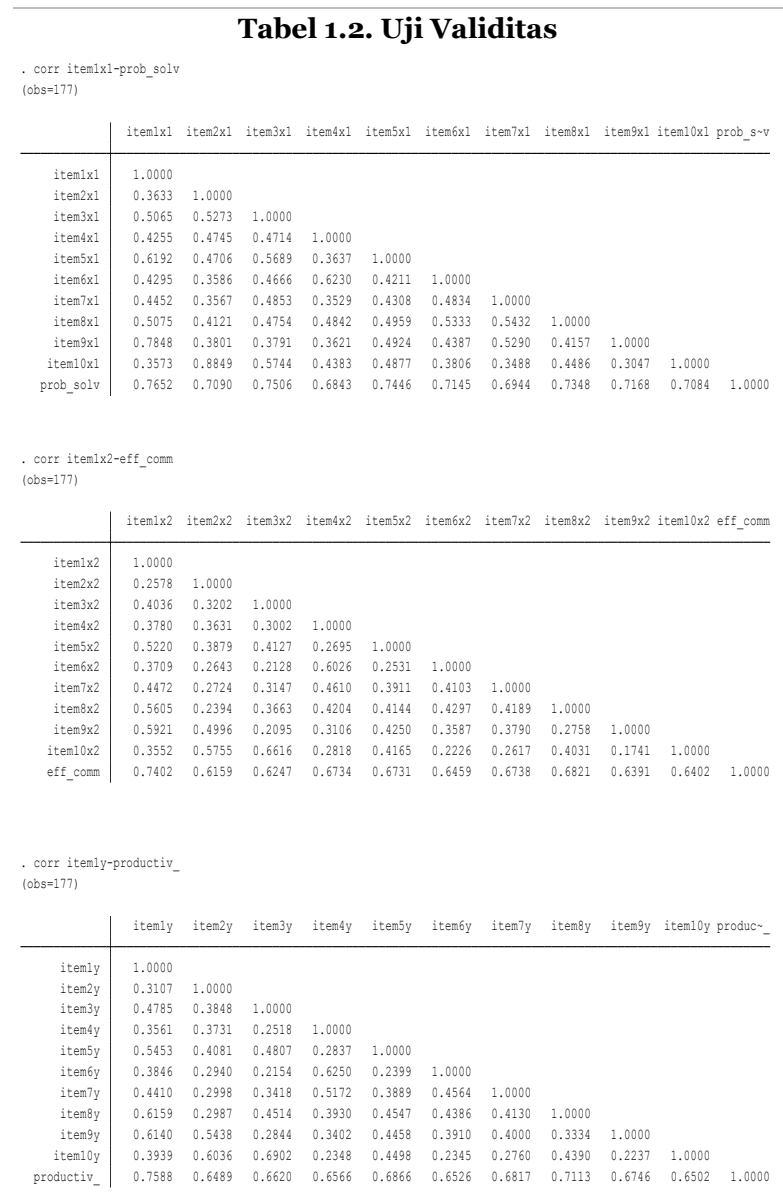

Berdasarkan tabel di atas menunjukkan bahwa nilai keseluruhan untuk uji validitas (r-hitung) memiliki nilai lebih besar dari nilai (r-tabel). Berdasarkan perhitungan dari 10 item yang dikalibrasi setelah validitasnya menggunakan STATA $\mathbf{1 4 . 2}$ menghasilkan data yang valid. Dengan nilai rata-rata 0,7222 di mana menurut Guilford nilai rata-rata adalah $0,60<$ rxy 0,79 berarti Problem Solving Skill memiliki validitas yang kuat atau tinggi. Dengan nilai rata-rata o,6608 dimana menurut Guilford nilai ratarata adalah $0,60 \quad<$ rxy 0,79 berarti Komunikasi Efektif memiliki validitas yang kuat atau tinggi. Dengan nilai rata-rata o,6783 dimana menurut Guilford nilai ratarata adalah 0,60 < rxy 0,79 berarti bahwa produktivitas Karyawan memiliki validitas yang kuat atau tinggi.

\section{Uji Reliabilitas}

Tabel 1.3. Hasil Uji Reliabilitas

\begin{tabular}{|cccc|}
\hline No & Variables & $\begin{array}{c}\text { The Result of Reliability } \\
\text { Test }\end{array}$ & Note \\
\hline $\mathbf{1}$ & Problem Solving Skill & 0.8976 & Sangat Kuat \\
\hline $\mathbf{2}$ & Komunikasi Efektif & 0.8553 & Sangat Kuat \\
\hline $\mathbf{3}$ & Produktivitas Karyawan & 0.8681 & Sangat Kuat \\
\hline
\end{tabular}

Berdasarkan tabel 3 Uji reliabilitas Problem Solving Skill, dapat disimpulkan bahwa instrumen variabel kompetensi dapat dinyatakan reliabel karena nilai cronbach alpha Problem Solving Skill lebih besar yaitu o,8976> 0,60. Dalam Uji Reliabilitas Komunikasi Efektif, dapat disimpulkan bahwa instrumen variabel Komunikasi Efektif dapat dinyatakan reliabel karena nilai cronbach alpha Pengembangan Karier lebih besar pada o,8553> o,60. Uji reliabilitas produktivitas karyawan dapat disimpulkan bahwa instrumen variabel produktivitas Karyawan dapat dinyatakan reliabel karena nilai cronbach alpha dari produktivitas Karyawan lebih besar yaitu o,8681> 0,60. 


\section{Uji Asumsi Klasik}

\section{Uji SaphiroWilk}

Tabel 1.4. Uji SaphiroWilk

Shapiro-Wilk w test for normal data

\begin{tabular}{c|ccccc} 
Variable & Obs & W & V & z & Prob $>z$ \\
\hline residuals & 177 & 0.94582 & 7.269 & 4.536 & 0.00000
\end{tabular}

Berdasarkan tabel 1.4 di atas, dapat dilihat nilai probabilitas $0,0000<0,05$ atau p-value $<5 \%$, maka Ho ditolak; Ha diterima. Jadi Saphiro Wilk memenuhi asumsi normalitas.

\section{Analisis Koefisien Korelasi}

\begin{tabular}{r|ccc}
\multicolumn{4}{c}{ Tabel 1.5. Uji Koefisien Korelasi } \\
& produc _ prob_s v eff_comm \\
\hline productiv_ & 1.0000 & & \\
prob_solv & 0.6852 & 1.0000 & \\
eff_comm & 0.9302 & 0.6091 & 1.0000
\end{tabular}

Berdasarkan tabel 1.5. diperoleh hasil yang diperoleh dengan menggunakan program STATA 14.2 dapat dijelaskan bahwa:

a. Besarnya nilai korelasi antara variabel Problem Solving Skill dan variabel produktivitas karyawan adalah 0,6852, nilai r-hitung > r-tabel $(0,6852>0,1476)$ memiliki hubungan yang kuat.

b. Besarnya nilai korelasi antara variabel Komunikasi Efektif dan Produktivitas Karyawan adalah 0,9302, maka nilai rhitung $>$ r-tabel $(0,9302>\quad 0,1476)$ memiliki hubungan yang sangat kuat.

\section{Koefisien Determinasi Analisis ( $\left.\mathbf{R}^{2}\right)$}

\begin{tabular}{|c|c|c|c|c|c|c|}
\hline \multicolumn{7}{|c|}{ Tabel 1.6. Uji Analisis Determinasi ( $\left.R^{2}\right)$} \\
\hline Source & SS & df & MS & Number of obs & $=$ & 177 \\
\hline Model & 4499.89345 & 2 & 2249.94673 & Prob $>\mathrm{F}$ & $=$ & 0.0000 \\
\hline Residual & 569.835363 & 174 & 3.27491588 & R-squared & $=$ & 0.8876 \\
\hline Total & 5069.72881 & 176 & 28.8052773 & Root MSE & $=$ & 1.8097 \\
\hline
\end{tabular}

Koefisien determinasi $\left(\mathrm{R}^{2}\right)$ sebesar o,8876, dapat disimpulkan bahwa Problem Solving Skill dan Komunikasi Efektif berkontribusi terhadap produktivitas kerja karyawan sebesar 88,76\% sedangkan sisanya dipengaruhi oleh faktor lain yang tidak diteliti dalam penelitian ini.

\section{Analisis Regresi Linier Berganda}

Tabel 1.7. Regresi Linier Berganda

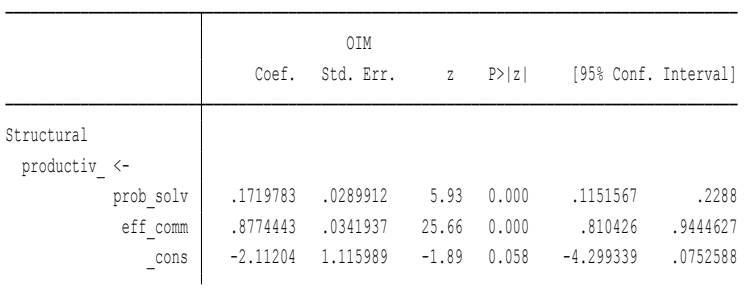

Koefisien regresi $\beta$ PSP $=0,17$. Nilai konstantanya adalah -2.11, yang berarti bahwa produktivitas karyawan akan sebesar 2.11 jika tidak dipengaruhi oleh koefisien regresi Problem Solving Skill. Koefisien jalur $\beta \mathrm{ECP}=0,87$. Nilai konstanta adalah -2.11, yang berarti bahwa produktivitas Karyawan akan sebesar -2.11 jika tidak dipengaruhi oleh koefisien regresi Komunikasi Efektif.

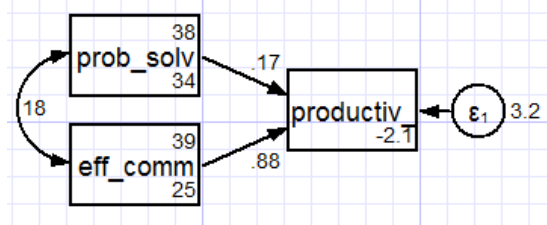

Gambar 1.1. Regresi Linier 
$\mathrm{Y}=\alpha+\beta 1 \mathrm{PS}+\beta_{2} \mathrm{EC}+\varepsilon 1$

$\mathrm{Y}=-2.1+0.17 \mathrm{PS}+0.88 \mathrm{EC}+3.2$

$\mathrm{Y}=-2.1+0.17$ Problem solving skill +0.88

Effective Communication +14

a. Koefisien jalur $\beta$ PS $=0,17$. Nilai konstanta adalah -2.1, yang berarti bahwa produktivitas karyawan akan sebesar 5.1 jika tidak dipengaruhi oleh koefisien regresi Problem Solving Skill. Dengan nilai signifikansi $(0,000>0,05)$ maka Ho ditolak dan Ha diterima, artinya koefisien analisis jalur signifikan.

b. b. Koefisien jalur $\beta \mathrm{EC}=0,88$. Nilai konstanta adalah -2.1, yang berarti bahwa produktivitas Karyawan akan sebesar -2.1 jika tidak dipengaruhi oleh koefisien regresi Komunikasi Efektif. Dengan nilai signifikansi (o,0oo> 0,05) maka Ho ditolak dan Ha diterima, artinya koefisien analisis jalur signifikan.

\section{Uji Signifikansi Parsial (Uji-T)}

Tabel 1.8. Uji Signifikansi Parsial (Uji-t)

\begin{tabular}{r|rrrrrr}
\hline productiv_ & Coef. & Std. Err. & $\mathrm{t}$ & $\mathrm{p}\rangle|\mathrm{t}|$ & \multicolumn{1}{l}{ [95\% Conf. Interval] } \\
\hline prob_solv & .1719783 & .02924 & 5.88 & 0.000 & .1142676 & .2296891 \\
eff_comn & .8774443 & .0344872 & 25.44 & 0.000 & .8093773 & .9455114 \\
_cons & -2.11204 & 1.125569 & -1.88 & 0.062 & -4.333566 & .1094855 \\
\hline
\end{tabular}

Berdasarkan tabel 1.8 di atas, dengan nilai (t-hitung $>$ t-tabel) yaitu $(5,88>1,97)$ dan dengan nilai signifikansi $(0,000<0,05)$ maka Problem Solving Skill secara parsial memiliki pengaruh yang signifikan terhadap produktivitas karyawan. Dengan nilai (t- hitung $>\mathrm{t}$ tabel) yaitu $(25,44>1,97)$ dan dengan nilai signifikansi (o,00o <0,05), Komunikasi Efektif secara parsial memiliki pengaruh signifikan terhadap produktivitas Karyawan.

\section{Uji Simultan (Uji-F)}

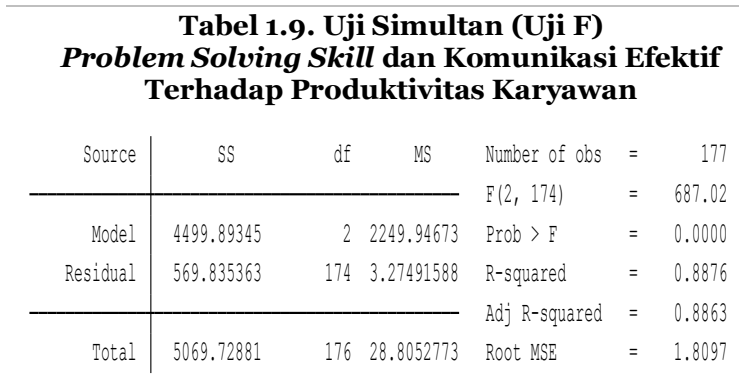

Berdasarkan tabel 1.9. dapat dilihat hasil uji-F dengan nilai (t-hitung $>\mathrm{F}$-tabel) yaitu $(687,02>3,05)$ dan dengan nilai signifikansi $(0,0000<0,05)$ maka Problem Solving Skill dan Komunikasi Efektif secara simultan memiliki pengaruh signifikan terhadap produktivitas karyawan.

\section{SIMPULAN}

Berdasarkan hasil penelitian di PT Reckitt Benckiser Indonesia, terdapat pengaruh parsial positif dan signifikan antara Problem Solving Skill dan produktivitas karyawan. Problem Solving Skill di PT Reckitt Benckiser Indonesia memungkinkan karyawan untuk memecahkan masalah dengan lebih cepat. Saat dihadapkan dengan suatu masalah, akan lebih mudah untuk berbicara secara terbuka dengan rekan kerja dan manajer untuk menyelesaikan masalah. Jika karyawan tidak secara jelas dan jujur 
mengomunikasikan masalah ini, mereka mungkin tidak pernah menemukan solusi. Jika seorang karyawan berjuang untuk menyelesaikan proyek karena masalah teknis, berkomunikasi dengan rekan-rekan mereka dapat membantu menyelesaikan masalah.

Ada pengaruh parsial positif dan signifikan antara komunikasi yang efektif dan produktivitas karyawan. Komunikasi yang efektif dapat membantu bisnis untuk mengurangi kesalahan informasi dan kesalahpahaman yang mengarah pada kesalahan. Masalah yang ada dapat secara drastis mengurangi produktivitas karyawan di PT Reckitt Benckiser Indonesia. Ketika karyawan jelas tentang apa yang perlu dilakukan, daripada membuat asumsi atau menebak, mereka bekerja yang mereka hasilkan akan lebih akurat. Mengembangkan kompetensi karyawan dalam hal sikap dan komunikasi secara aktif membangun kerja tim dengan kepercayaan pada tim.

Ada pengaruh positif simultan dan signifikan antara Problem Solving Skill dan komunikasi yang efektif yaitu Problem Solving Skill dan komunikasi yang efektif secara bersama-sama memberikan arahan dan sosialisasi mengenai tujuan perusahaan dengan komunikasi yang baik dengan karyawan. Karyawan juga harus memahami informasi yang disampaikan oleh pimpinan. Komunikasi yang disampaikan oleh pimpinan harus dapat memotivasi karyawan.
Komunikasi dapat dilakukan secara lisan atau tertulis antara pimpinan dan karyawan dan sesama karyawan._Agar Problem Solving Skill dan komunikasi menjadi lebih efektif, penyampaian informasi antara pemimpin dan karyawan, dan sesama karyawan harus menggunakan bahasa yang mudah dipahami sehingga miskomunikasi tidak terjadi. Pemimpin dapat mengadakan rapat dan rapat untuk membahas masalah atau hambatan yang muncul di antara karyawan. Adanya keterbukaan dalam komunikasi dapat melalui pertukaran informasi antara pimpinan dengan karyawan dan sebaliknya. Karyawan dapat mengajukan pertanyaan, ide, dan saran mengenai implementasi pekerjaan. Karyawan dapat berkomunikasi dengan baik dengan semua pihak di perusahaan sehingga mereka dapat bekerja sama.

\section{DAFTAR PUSTAKA}

Akhtar, Naeem. 2014. Impact of Training on Employees productivity of Employees: A Case Study of Electricity Supply Company in Pakistan. InternationalReview of Management and BusinessResearch. Vol. 3 Issue.2. SSN: 2306-9007. Pakistan.

Allen, Louis A. 2011. Attitudes, Personality, and Behaviour. Open University Press. New York.

Amstrong, M.2014. Manajemen Sumber Daya Manusia. Kompetindo. Jakarta. 
Appley, A. Lawrence. 2015. Organization Learning. A Theory of Action Perspective Reading. Allyn and Bacon. Boston.

Arifin, Tajur. 2013. Organizational Behavior. McGraw-Hill Companies, Inc. New York.

Arikunto. 2015. Prosedur Penelitian Pendekatan Praktik. Rineka Cipta. Jakarta.

Bungin, Burhan. 2014. Metodologi Penelitian Kuantitatif Ekonomi, Komunikasi, dan Kebijakan Publik Serta Ilmu-Ilmu Sosial Lainnya. Kencana Prenada Media Group. Jakarta.

Cylwik, Longina Strumska. 2013. Stress and Communication (I.E On Stress in Communication and Communication Under Stress). International Journal of Arts \& Sciences. ISSN: 1944-6934 :: 6(3):419-441 (2013) Poland.

Egeci, I. Sine. 2012. The Effects of Attachment Styles, Problem-Solving Skills, and Communication Skills on Relationship Satisfaction. Procedia Social and Behavioral Sciences 30 (2011) 2324 - 2329. Turkey.

Erozkan, Atilgan. 2013. The Effect of Communication Skills and Interpersonal Problem solving skill on Social Self-Efficacy. Educational Sciences: Theory \& Practice - 13(2) 739745. Turkey.
Flippo, Edwin B. 2014. Personnel Management. Hill Book Company. New York. , 2016. The Greatest Networker in The World. The Three Rivers Press. New York.

Follet, Mary Parker. 2015. Behavior in Organizations. Prentice Hall. New Jersey.

Gibson, James L, John M.I, James H. Donnely. 2009. Organisasi, Prilaku, Struktur, Proses. Edisi Kedelapan. Bina Aksara. Jakarta.

Ghozali, Imam. 2013. Aplikasi Analisis Multivariate. Universitas Diponegoro. Semarang

Gomes. 2015. Manajemen Sumber Daya Manusia. Penerbit Andi. Yogyakarta.

Gomulya, Berny. 2012. Problem Solving And Decision Making for Improvement. Gramedia. Jakarta.

Gordon. 2015. ManajemenPerilaku Organisasi dan Pendayagunaan Sumber DayaManusia. Erlangga. Jakarta.

Griffin, Ricky W. 2014. Bussines. Prentice Hall International Inc. New Jersey.

Handoko, T.Hani. 2010. Manajemen Personalia dan Sumber Daya Manusia. BPFE. Yogyakarta.

Harninda. 2015. Manajemen Sumber Daya Manusia. Gramedia. Jakarta.

Harnoto. 2016. Manajemen Sumber Daya Manusia. Prehall Indo. Jakarta. 
Hasibuan, Malayu S.P. 2016. Manajemen, Dasar, Pengertian, dan Masalah. Bumi Aksara. Jakarta.

, 2016. Manajemen Sumber Daya Manusia. Bumi Aksara. Jakarta.

Heidjracman, Ranupanjojo, Suad Husnan. 2010. Manajemen Personalia. BPFE. Yogyakarta.

Iriantara, Yosal. 2014. Komunikasi Bisnis. Universitas Terbuka. Jakarta.

Jackson, John H. Mathis, Robert L. 2015. Human Resources Development (Track MBA Series). Prestasi Pustaka. Jakarta.

Kepner,C,H. \& Tregoe, B.B. 2012. The Rational Project Manager : A Thinking Team's Guide to Getting Work Done. Kepner Tregoe Method. Netherlands.

Kontour, Ronny. 2011. Good Communication. Prentice Hall. New Jersey.

Koontz, Harold. 2012. Management. Eight Edition. England.

Mangkunegara, Anwar Prabu. 2015. Manajemen Sumber Daya Manusia. Remaja Rosda Karya. Bandung. , 2015. Evaluasi Kinerja SDM. Refika Aditama. Bandung. , 2016. Manajemen Sumber Daya Manusia Perusahaan. Remaja Rosda Karya. Bandung

Manullang, M. 2011. Management Personalia. Ghalia Indonesia. Jakarta.
, 2016. Organisasi dan Motivasi Dasar Peningkatan Produktivitas. Bumi Aksara. Jakarta.

Marshall, Bruce. 2016. The impact of Career Development on Employees productivity: an empirical study of Brompton Bikes Factory in London. Journal International of Academic Research in Business and Social Sciences Vol. 4, No. 4 ISSN: 22226990.

Mobley. 2015. PergantianKaryawan : Sebab Akibat dan Pengendaliannya. Ghalia. Jakarta.

Moekijat. 2016. Manajemen Kepegawaian(Personnel Management). Alumni. Bandung. , 2016. Manajemen Sumber Daya Manusia. Mandar Maju. Bandung.

Nawawi. 2016. Sumber Daya Manusia untuk Bisnis yang Kompetitif. Prehalindo. Jakarta.

Nikitina, Arina. 2018. The Art of Problem solving skill. Bookboon.

Noe, Mondy. 2015. Manajemen Sumber Daya Manusia Mencapai Keunggulan Bersaing. Salemba Empat. Jakarta.

Noor, Juliansyah. 2012. Efektifitas Kinerja. Erlangga. Jakarta.

Okoro, Ephraim. 2017. The Impact of Interpersonal Communication Skills on Organizational

Effectiveness and Social Self-Efficacy: A Synthesis. International Journal of 
Language and Linguistics Vol. 4, No. 3 , September 201. ISSN 2374-8850 (Print), 2374-8869 (Online). USA. O'Neill, Tara. Light, Janice. Pope, Lauramarie. 2018. Effects of Interventions That Include Aided Augmentative and Alternative Communication Input on the Communication of Individuals with Complex Communication Needs: A Meta-Analysis. Journal of Speech, Language and Hearing Research (Online); Vol. 61, Iss. 7, : 1743-1765. Rockville.

Polat G. B., \& Keşan, C. (2013). Researching about relations between problem solving skill in maths and comprehension skills in turkish for 7 th and 8th grade students'. International Online Journal of Primary Education,2(2), 23-29.

Priyatno. 2011. BukuSaku Analisis Statistik Data. Mediakom. Yogyakarta.

Rivai. 2015. Manajemen Sumber Daya Manusia untuk Perusahaan dari Teori ke Praktek. Raja Grafindo Persada. Jakarta.

Robbin, Stephen. 2015. Organizational Behaviour. Prentice Hall. New Jersey. , 2016. Manajemen. - Ed X, Jilid 1. Erlangga. Jakarta.

Roe, Robert A. 2015. Human Relations in Organiszation Applications and Skill Building. Mc Graw Hill. New York.
Ruky. 2015. Sumber Daya Manusia Berkualitas Mengubah Visi Menjadi Realita. Gramedia Pustaka. Jakarta. Sanusi, Anwar. 2012. Manajemen Sumber Daya Manusia. Raja Grafindo. Jakarta. Sedarmayanti. 2015. Sumber Daya Manusia dan Produktivitas Kerja. Mandar Maju, Bandung.

Siagian, Sondang, P. 2015. Manajemen Stratejik. Bumi Aksara. Bandung. , 2016. Manajemen Sumber Daya Manusia. Bumi Aksara. Bandung. Siburian, Tiur Asi. 2013. The Effect of Interpersonal Communication, Organizational Culture, Job Satisfaction, and Achievement Motivation to Organizational Commitment of State High School Teacher in the District Humbang Hasundutan, North Sumatera. International Journal of Humanities and Social Science Vol. 3 No. 12. Indonesia

Simamora. 2015. Manajemen Sumber Daya Manusia. STIE YKPN. Yogyakarta.

Singh, A.K. (2014). Role of interpersonal communication in organizational effectiveness. International Journal of Research in Management and Business Studies (IJRMBS). Volume 1, Issue 4 (ISSN: 2348-6503)

Soeprihanto. 2016. Penelitian Kinerja dan Pengembangan Karyawan. BPFE. Yogyakarta. 
Sugiyono. 2010. Prosedur Penelitian. Rineka Cipta. Jakarta.

2012. Metode Penelitian Kuantitatif dan Kualitatif. Alfabeta. Bandung.

_ 2015. Metode Penelitian Administratif. Alfabeta. Bandung. , 2016. Metode Penelitian Pendidikan (Pendekatan Kuantitatif, Kualitatif dan $R \& D)$. Alfabeta. Bandung.

Sunyoto, Danang. 2015. Sistem Informasi Manajemen. CAPS. Yogyakarta.

Sutrisno. 2015. Memotivasi dan Pemotivasian dalam Manajemen. Raja Grafindo. Jakarta.

Sutrisno, Edy. 2012. Manajemen Sumber Daya Manusia. Kencana Prenada Media Group. Jakarta.

Tahir, Neelam. 2014. The Impact of Training and Development on Employees Performance and Employees productivity a case study of United Bank Limited Peshawar City, KPK, Pakistan, International Journal of Academic Research in Business and Social Sciences, Vol. 4, No. 4ISSN: 2222-6990.

Terry, George. 2012. Management of Organizational Behavior. Prentice Hall. New Jersey.

2014. Dasar-Dasar Manajemen, (Terjemahan G.A Ticoalu). Bumi Aksara. Jakarta.
2015. Prinsip-Prinsip Manajemen, (Terjemahan Winardi). Bumi Aksara. Jakarta.

, 2016. Management Skill for Manager. American Management Association. New Jersey.

Triatna, Cepi. 2016. Perilaku Organisasi. Remaja Rosda Karya Offset. Bandung. Ulu, Mustafa. 2017. The Effect of Reading Comprehension and Problem Solving Strategies on Classifying Elementary 4th Grade Students with High and Low Problem Solving Success. Journal of Education and Training Studies. Vol. 5, No. 6; June 2017. ISSN 2324-805X EISSN 2324-8068. Turkey.

Umar. 2014. Desain Penelitian MSDM dan Perilaku Karyawan. Raja Grafindo Persada. Jakarta.

Universitas Pamulang. 2013. Buku Panduan Penulisan Tesis. Program Pascasarjana Magister Manajemen Universitas Pamulang. Tangerang Selatan.

Wan, Ong Teong. 2012. Manajemen Hasil. Gramedia. Jakarta.

Yurt, E., \& Sünbül, A. M. (2014). A Structural Equation Model Explaining the Mathematics Achievements of the $8^{\text {th }}$ Grade Students. Educational Sciences: Theory \& Practice, 14(4), 1629-1653 